\title{
Biomass and carbon stocks in three types of Persian oak (Quercus brantii var. persica) of Zagros forests in a semi-arid area, Iran
}

\author{
Ali MAHDAVI ${ }^{1 *}$, Soghra SAIDI ${ }^{1}$, Yaghob IRANMANESH ${ }^{2}$, Mostafa NADERI $^{1}$ \\ ${ }_{1}^{1}$ Faculty of Agriculture and Natural Resources, Ilam University, Ilam 69315516, Iran; \\ ${ }^{2}$ Research Division of Natural Resources, Chaharmahal and Bakhtiari Agricultural and Natural Resources Research and \\ Education Center, AREEO, Shahrekord 8818434141, Iran
}

\begin{abstract}
Persian oak (Quercus brantii var. persica) is a dominant tree species of Zagros forests in a semi-arid area, western Iran. However, the capacity of biomass and carbon stocks of these forests is not well studied. We selected three types of oak, i.e., seed-originated oak, coppice oak and mixed (seed-originated and coppice) oak of Zagros forests in Dalab valley, Ilam Province, Iran to survey the capacity of biomass and carbon stocks in 2018. Thirty plots with an area of $1000 \mathrm{~m}^{2}$ were systematically and randomly assigned to each type of oak. Quantitative characteristics of trees, such as diameter at breast height $(\mathrm{DBH})$, height, crown diameter and the number of sprouts in each plot were measured. Then, aboveground biomass (AGB), belowground biomass (BGB), aboveground carbon stock (AGCS) and belowground carbon stock (BGCS) of each tree in plots were calculated using allometric equations. The litterfall biomass (LFB) and litterfall carbon stock (LFCS) were measured in a quadrat with $1 \mathrm{~m} \times 1 \mathrm{~m}$ in each plot. One-way analysis of variance and Duncan's test were performed to detect the differences in biomass and carbon stocks among three types of oak. Results showed that AGB, BGB and BGCS were significantly different among three types of oak. The highest values of AGB, AGCS, BGB and BGCS in seed-originated oak were 76,043.25, 14,725.55, 36,737.79 and $7362.77 \mathrm{~kg} / \mathrm{hm}^{2}$, respectively. Also, the highest values of LFB and LFCS in seed-originated oak were 3298.33 and $1520.48 \mathrm{~kg} / \mathrm{hm}^{2}$, respectively, which were significantly higher than those of the other two types of oak. The results imply the significant role of seed-originated oak for the regeneration of Zagros forests. Further conservation strategy of seed-originated oak is an important step in the sustainable management of Zagros forests in Iran.
\end{abstract}

Keywords: biomass; carbon stock; seed-originated forest; coppice forest; Zagros forest

Citation: Ali MAHDAVI, Soghra SAIDI, Yaghob IRANMANESH, Mostafa NADERI. 2020. Biomass and carbon stocks in three types of Persian oak (Quercus brantii var. persica) of Zagros forests in a semi-arid area, Iran. Journal of Arid Land, 12(5): 766-774. https://doi.org/10.1007/s40333-020-0027-4

\section{Introduction}

Increasing greenhouse gases including carbon dioxide $\left(\mathrm{CO}_{2}\right)$ has been identified as the source of global warming or abrupt climate change (Allen et al., 2006; Lorenz and Lal, 2010). Human activities for reducing atmospheric $\mathrm{CO}_{2}$ were started when the impacts of global warming were specified (Sohrabi et al., 2016). The increase rate of atmospheric $\mathrm{CO}_{2}$ concentration can be reduced through the process of carbon sequestration (Lorenz and Lal, 2010). Carbon stocks in tree biomass and forest soils are economically considered as the most possible procedures to reduce atmospheric carbon (Brown, 1996). Trees play an important role in reducing atmospheric $\mathrm{CO}_{2}$ by absorbing and accumulating in their leaves, branches, stems and roots as biomass (McPherson and

\footnotetext{
*Corresponding author: Ali MAHDAVI (E-mail: mahdaviali56@gmail.com)

Received 2018-12-18; revised 2020-09-03; accepted 2020-09-13

(C) Xinjiang Institute of Ecology and Geography, Chinese Academy of Sciences, Science Press and Springer-Verlag GmbH Germany, part of Springer Nature 2020
} 
Simpson, 1999). The aboveground biomass (AGB) in trees generally accounts for the greatest fraction of total living biomass in a forest (Brown, 2002). Forest productivity and aboveground carbon stock (AGCS) are also related with many factors, such as tree size inequality, stand age, nutrient regime and climate anomalies (Chen and Luo, 2015). Changes in stand characteristics through forest succession have significant impacts on forest productivity and AGCS (Becknell and Powers, 2014). This is because tree size inequality among and within species is critical toward maintaining the species diversity, diameter at breast height (DBH) and height (Wang et al., 2011), which has been recognized to significantly affect forest carbon stocks (Lexerød and Eid, 2006; Zhang and Chen, 2015).

The amount of AGB in a region can be estimated either by direct or indirect methods. The direct method consists of cutting and weighing the AGB in an established area. This method is destructive and very time-consuming. Therefore, allometric equations are often used for estimating forest biomass. Allometric equations relate the biomass of individual trees to easily obtainable and nondestructive measurements, such as diameter, height and wood density (Chave et al., 2005). It has been demonstrated that choosing suitable allometric equations for each forest type is of great importance, because biomass and associated carbon estimates are highly sensitive to the choice of allometric equations (Jepsen, 2006). More accurate biomass estimations will be obtained when region-specific allometric equations will be developed (Pearson et al., 2007). For example, Iranmanesh et al. (2013) determined the allometric equations for different Persian oak trees (seed-and coppice-originated) by destructive method in Zagros forests, Iran.

Zagros forests, with an area of $6 \times 10^{6} \mathrm{hm}^{2}$, play important roles in water supply, soil conservation, climate change and socioeconomic balance in the semi-arid area, Iran (Sagheb-Talebi et al., 2014). However, Zagros forests significantly decreased due to forest clearance for cultivation, non-wood forest products exploitation, overharvesting and overgrazing, pollarding and firewood collection (Soltani et al., 2014). The Persian oak (Quercus brantii var. persica) is a dominant tree species of Zagros forests. We found three types of regeneration in oak based on their silvicultural characteristics, i.e., seed-originated oak, coppice oak and mixed (seed-originated and coppice) oak. Coppice stands that are characterized by sprout-clumps are formed asexually/vegetatively through sprouting. Seed-originated stands that account for less than $10 \%$ in Zagros forests are dense and usually distribute in remote areas with old oak trees. And the diameter at breast height (DBH) of the old oak trees is higher than $80 \mathrm{~cm}$. Mixed stands usually have two layers, in which the upper layer forms by seed-originated oak and the lower layer forms by sprout-clumps of oak (Sagheb-Talebi et al., 2014). Researches for assessing biomass and carbon stocks have been focused on Hyrcanian forests in Iran, however, less attention was paid to Zagros forests. This study analyzed the biomass and carbon stocks of three types of Persian oak to understand their contributions on regeneration of Zagros forests and provide a guideline for sustainable management of Zagros forests in Iran.

\section{Materials and methods}

\subsection{Study area}

This study was conducted in Dalab valley with an area of $3000 \mathrm{hm}^{2}\left(33^{\circ} 41^{\prime} 01^{\prime \prime}-33^{\circ} 43^{\prime} 13^{\prime \prime} \mathrm{N}\right.$, $46^{\circ} 22^{\prime} 15^{\prime \prime}-46^{\circ} 25^{\prime} 27^{\prime \prime} \mathrm{E}$; $1200-2000 \mathrm{~m}$ a.s.l.) in Ilam Province, Iran. The study area has a cold and semi-arid climate with dry months extending from May to November. The mean annual precipitation is $525.0 \mathrm{~mm}$ (mainly occurs in winter) and the annual mean temperature is $16.9^{\circ} \mathrm{C}$. In the study area, three types of Persian oak, i.e., seed-originated oak, coppice oak and mixed (seed-originated and coppice) oak were selected. There are no significant climatic differences in the study area among the three types of oak, and the topographic of slope, aspect, elevation and soil conditions are similar. Other accompanied tree species in the study area are Pistacia atlantica, Acer monspessulanum and Amygdalus eleagnifolia.

\subsection{Field measurements}

Thirty circular-shaped sample plots with an area of $1000 \mathrm{~m}^{2}$ were assigned to the three types of 
oak in a randomly systematic design. In each plot, indices of Persian oak including DBH $(>5 \mathrm{~cm})$, height, crown diameter and the number of sprouts (in coppice oak) were measured and recorded. All measured indices were calculated for each plot and averaged per hectare for each type of oak.

\subsection{AGB and AGCS}

For individual trees $(\mathrm{DBH}>5 \mathrm{~cm})$ and coppice trees, AGB $\left(\mathrm{kg} / \mathrm{hm}^{2}\right)$ and AGCS $\left(\mathrm{kg} / \mathrm{hm}^{2}\right)$ were calculated using the Iranmanesh's allometric equations (Iranmanesh, 2013).

Allometric equations for AGB and AGCS estimations of seed-originated oak were as follows:

$$
\begin{aligned}
& \mathrm{AGB}=0.881 X^{3.228}, \\
& \mathrm{AGCS}=0.425 X^{3.230},
\end{aligned}
$$

where $X$ is the average crown diameter $(\mathrm{m})$.

Allometric equations for AGB and AGCS estimations of coppice oak were as follows:

$$
\begin{aligned}
& \mathrm{AGB}=2.534 X^{2.383}, \\
& \mathrm{AGCS}=1.275 X^{2.262} .
\end{aligned}
$$

\subsection{BGB and BGCS}

We estimated BGB of Persian oak based on a nondestructive method. We used the root to shoot ratio that was suggested by Askari et al. (2017) to estimate BGB. In this estimation, the average ratio of root to shoot in seed-originated and coppice oaks is considered as 0.8. Additionally, the coefficient of 0.5 for the conversion biomass into carbon was applied to obtain BGCS (Hernandez et al., 2004).

\subsection{LFB and LFCS}

To estimate the carbon content in tree litterfall, we randomly placed a quadrat with $1 \mathrm{~m} \times 1 \mathrm{~m}$ inside each plot (total 30 samples). Samples were dried at $70^{\circ} \mathrm{C}$ to a constant weight (Nunes et al., 2013).

The percentage of organic carbon (Ash) in each sample was measured by the combustion method in electric furnace. And carbon coefficient $(C)$ of litterfall was estimated by the following equations (Allen et al., 1986):

$$
\begin{aligned}
& \text { Ash }=\frac{W_{3}-W_{1}}{W_{2}-W_{1}} \times 100 \%, \\
& C=(100 \%-\text { Ash }) \times 0.58,
\end{aligned}
$$

where Ash is the percentage of ash after burning (\%), which represents the organic carbon; $W_{3}$ is the sum of the weights of ash and vase $(\mathrm{g}) ; W_{1}$ is the weight of vase $(\mathrm{g}) ; W_{2}$ is the dry weight of sample $(\mathrm{g})$; and $C$ is the carbon coefficient (\%).

\subsection{Statistical analysis}

The normality of the data was tested using Kolmogorov-Smirnov test. We used a one-way analysis of variance (ANOVA) to test the equality of means in AGB, BGB, AGCS and BGCS among the three types of oak. Then, a comparison of mean values of these variables was done by Duncan's test to find the differences. All statistical analyses were performed using IBM SPSS Statistics (version 16).

\section{Results}

\subsection{Forest characteristics}

We selected 1036 trees among three types of oak and measured $\mathrm{DBH}$, height, crown diameter and sprouts in 2017. We divided DBH and crown diameter into three diameter classes (i.e., $<30$, $30-60$ and $>60 \mathrm{~cm} ;<5,5-15$ and $>15 \mathrm{~m}$, respectively) and two height classes (i.e., $<5$ and $5-15$ $\mathrm{m})$. Table 1 shows the quantitative characteristics of three types of oak. Results indicated that most of trees $(93.70 \%)$ were in the smallest diameter classes $(\mathrm{DBH}<30 \mathrm{~cm})$ and less than $1.00 \%$ 
of trees had a $\mathrm{DBH}>60 \mathrm{~cm}$ (probably these trees had a seed origin) in coppice forest. Most of trees $(61.03 \%)$ had a DBH of $30-60 \mathrm{~cm}$ and $33.10 \%$ of trees had a $\mathrm{DBH}<30 \mathrm{~cm}$ in seed-originated oak. Most of trees $(65.48 \%$ ) had a $\mathrm{DBH}<30 \mathrm{~cm}$ and $34.25 \%$ of trees had a DBH of $30-60 \mathrm{~cm}$ in mixed oak. From the above results, we found that coppice and mixed oaks had a higher percentage of trees with a $\mathrm{DBH}<30 \mathrm{~cm}$, while seed-originated oak had the highest percentage of trees with a $\mathrm{DBH}>60 \mathrm{~cm}$ (Table 1). In coppice and seed-originated oaks, the highest frequency of tree height was observed in the class of 5-15 $\mathrm{m}$, while in mixed oak, the highest frequency of tree height in the class of $<5 \mathrm{~m}$ was observed (Table 1).

Table 1 Diameter at breast height (DBH), height and crown diameter in the three types of Persian oak

\begin{tabular}{|c|c|c|c|c|c|c|c|}
\hline Type & $\mathrm{DBH}(\mathrm{cm})$ & $\begin{array}{l}\text { Number } \\
\text { of trees }\end{array}$ & $\begin{array}{l}\text { Percentage } \\
\text { of trees }(\%)\end{array}$ & Height (m) & $\begin{array}{l}\text { Number } \\
\text { of trees }\end{array}$ & $\begin{array}{c}\text { Crown } \\
\text { diameter }(\mathrm{m})\end{array}$ & $\begin{array}{l}\text { Number } \\
\text { of trees }\end{array}$ \\
\hline \multirow[t]{4}{*}{ Coppice oak } & $<30$ & 357 & 93.7 & $<5$ & 161 & $<5$ & 229 \\
\hline & $30-60$ & 21 & 5.5 & $5-15$ & 220 & $5-15$ & 152 \\
\hline & $>60$ & 3 & 0.8 & - & - & $>15$ & 0 \\
\hline & Total & 381 & 100.0 & Total & 381 & Total & 381 \\
\hline \multirow[t]{4}{*}{ Seed-originated oak } & $<30$ & 96 & 33.1 & $<5$ & 12 & $<5$ & 26 \\
\hline & $30-60$ & 177 & 61.03 & $5-15$ & 278 & $5-15$ & 261 \\
\hline & $>60$ & 17 & 5.87 & - & - & $>15$ & 3 \\
\hline & Total & 290 & 100.0 & Total & 290 & Total & 290 \\
\hline \multirow[t]{4}{*}{ Mixed oak } & $<30$ & 239 & 65.5 & $<5$ & 200 & $<5$ & 292 \\
\hline & $30-60$ & 125 & 34.2 & $5-15$ & 165 & $5-15$ & 73 \\
\hline & $>60$ & 1 & 0.3 & - & - & $>15$ & 0 \\
\hline & Total & 365 & 100.0 & Total & 365 & Total & 365 \\
\hline
\end{tabular}

Note: - means no value.

\subsection{Biomass and carbon stocks}

Table 2 shows the average biomass and carbon stocks in the three types of oak. The highest value in AGB was observed in seed-originated oak $\left(76,043.25 \mathrm{~kg} / \mathrm{hm}^{2}\right)$ and followed by coppice oak $\left(19,345.73 \mathrm{~kg} / \mathrm{hm}^{2}\right)$. In addition, the highest values of LFB and LFCS (3298.33 and 1520.48 $\mathrm{kg} / \mathrm{hm}^{2}$, respectively) were found in seed-originated oak. As shown in Table 2, the mean values of AGB $\left(786.65 \mathrm{~kg} / \mathrm{hm}^{2}\right)$ and AGCS $\left(380.05 \mathrm{~kg} / \mathrm{hm}^{2}\right)$ of single tree in seed-originated oak was higher than those of each group of sprout in coppice oak. Meanwhile, the lowest values of AGB $\left(113.02 \mathrm{~kg} / \mathrm{hm}^{2}\right)$ and AGCS $\left(53.71 \mathrm{~kg} / \mathrm{hm}^{2}\right)$ were found in mixed oak.

Table 2 Biomass and carbon stocks in the three types of Persian oak

\begin{tabular}{ccrrrrrr}
\hline Type & Size & $\begin{array}{c}\text { AGB } \\
\left(\mathrm{kg} / \mathrm{hm}^{2}\right)\end{array}$ & $\begin{array}{c}\text { AGCS } \\
\left(\mathrm{kg} / \mathrm{hm}^{2}\right)\end{array}$ & $\begin{array}{r}\text { BGB } \\
\left(\mathrm{kg} / \mathrm{hm}^{2}\right)\end{array}$ & $\begin{array}{c}\text { BGCS } \\
\left(\mathrm{kg} / \mathrm{hm}^{2}\right)\end{array}$ & $\begin{array}{r}\text { LFB } \\
\left(\mathrm{kg} / \mathrm{hm}^{2}\right)\end{array}$ & $\begin{array}{r}\text { LFCS } \\
\left(\mathrm{kg} / \mathrm{hm}^{2}\right)\end{array}$ \\
\hline Coppice oak & Sprout & $152.33^{\mathrm{b}}$ & $73.81^{\mathrm{b}}$ & $121.86^{\mathrm{b}}$ & $60.93^{\mathrm{b}}$ & - & - \\
& Plot & $1934.57^{\mathrm{b}}$ & $937.32^{\mathrm{b}}$ & $1547.65^{\mathrm{b}}$ & $773.82^{\mathrm{b}}$ & $0.13^{\mathrm{b}}$ & $0.06^{\mathrm{b}}$ \\
& Hectare & $19,345.73^{\mathrm{b}}$ & $9373.20^{\mathrm{b}}$ & $15,476.58^{\mathrm{b}}$ & $7738.29^{\mathrm{b}}$ & $1334.00^{\mathrm{b}}$ & $598.90^{\mathrm{b}}$ \\
Seed-originated oak & Tree & $786.65^{\mathrm{a}}$ & $380.05^{\mathrm{a}}$ & $629.32^{\mathrm{a}}$ & $314.66^{\mathrm{a}}$ & - & - \\
& Plot & $7604.25^{\mathrm{a}}$ & $3673.77^{\mathrm{a}}$ & $6083.46^{\mathrm{a}}$ & $3041.70^{\mathrm{a}}$ & $0.33^{\mathrm{a}}$ & $0.10^{\mathrm{a}}$ \\
& Hectare & $76,043.25^{\mathrm{a}}$ & $36,737.79^{\mathrm{a}}$ & $60,834.60^{\mathrm{a}}$ & $30,417.30^{\mathrm{a}}$ & $3298.33^{\mathrm{a}}$ & $1520.48^{\mathrm{a}}$ \\
& Tree & $113.02^{\mathrm{c}}$ & $53.71^{\mathrm{c}}$ & $90.41^{\mathrm{c}}$ & $45.20^{\mathrm{c}}$ & - & - \\
& Plot & $1375.00^{\mathrm{c}}$ & $653.46^{\mathrm{c}}$ & $1100.00^{\mathrm{c}}$ & $550.00^{\mathrm{c}}$ & $0.08^{\mathrm{c}}$ & $0.04^{\mathrm{c}}$ \\
& Hectare & $13,750.90^{\mathrm{c}}$ & $6534.65^{\mathrm{c}}$ & $11,000.72^{\mathrm{c}}$ & $5500.36^{\mathrm{c}}$ & $812.33^{\mathrm{c}}$ & $379.91^{\mathrm{c}}$ \\
\hline
\end{tabular}

Note: AGB, aboveground biomass; AGCS, aboveground carbon stock; BGB, belowground biomass; BGCS, belowground carbon stock; LFB, litterfall biomass; LFCS, litterfall carbon stock. - means no value. Different lowercase letters indicate significant differences among the three types of oak at $P<0.05$ level.

Figure 1 shows the percentages of AGCS in different DBH classes of the three types of oak. The results showed that trees with $\mathrm{DBH}<30 \mathrm{~cm}$ had the highest percentage of AGCS $(81.45 \%)$ in coppice oak, while trees with $30-60 \mathrm{~cm}$ DBH had the highest percentage of AGCS in 


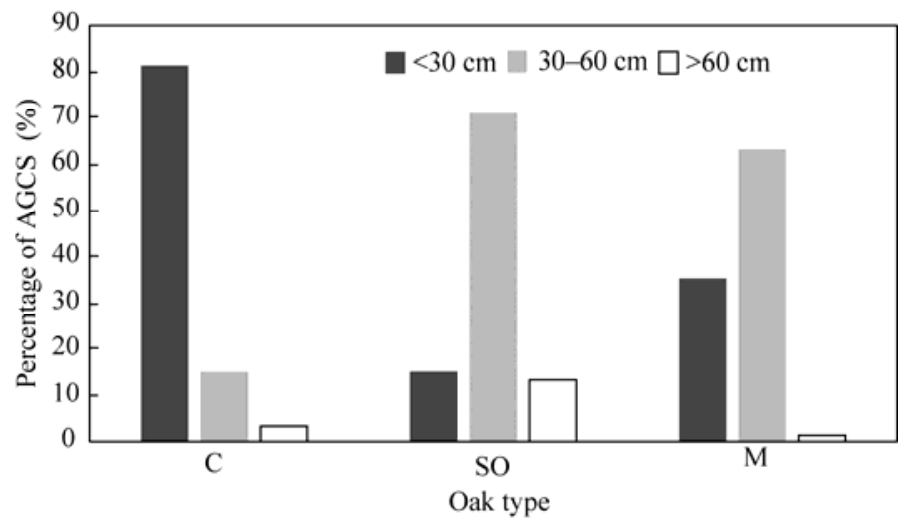

Fig. 1 Percentage of AGCS (aboveground carbon stock) in different DBH (diameter at breast height) classes of the three types of oak. C, coppice oak; SO, seed-originated oak; M, mixed oak.

seed-originated $(71.1 \%)$ oak and followed by the mixed $(63.2 \%)$ oak. Trees with $\mathrm{DBH}>60 \mathrm{~cm}$ contributed the least percentage of AGCS in the three types of oak. This result can be attributed to the lowest density of stems with the highest DBH class in the three types of oak.

Based on the result of ANOVA, there were significant differences in $\mathrm{DBH}$, height, crown diameter, LFCS, AGB, AGCS and BGCS among the three types of oak (Table 3). For all the variables, seed-originated oak had the significantly highest values than the other two types of oak (Fig. 2). The amounts of AGB, AGCS, BGCS and LFCS in coppice and mixed oaks were similar without significant differences (Fig. 2).

Table 3 Results of ANOVA for the quantitative characteristics of oak forests

\begin{tabular}{|c|c|c|c|c|c|c|}
\hline \multicolumn{2}{|c|}{ Source of variation } & Sum of square & $d f$ & Mean of square & $F$ & $P$ \\
\hline \multirow{3}{*}{$\mathrm{DBH}$} & Between groups & $67,160.89$ & 2 & $33,580.44$ & & \\
\hline & Within groups & $154,547.61$ & 1033 & 149.75 & 224.23 & $0.00^{* *}$ \\
\hline & Total & $221,708.50$ & 1035 & & & \\
\hline \multirow{3}{*}{ Height } & Between groups & 2869.45 & 2 & 1434.72 & & \\
\hline & Within groups & 4337.48 & 1033 & 4.19 & 341.69 & $0.00^{* *}$ \\
\hline & Total & 7206.93 & 1035 & & & \\
\hline \multirow{3}{*}{$\begin{array}{c}\text { Crown } \\
\text { diameter }\end{array}$} & Between groups & 3261.06 & 2 & 1630.53 & & \\
\hline & Within groups & 4146.25 & 1033 & 4.01 & 406.23 & $0.00^{* *}$ \\
\hline & Total & 7407.32 & 1035 & & & \\
\hline \multirow{3}{*}{ AGB } & Between groups & $89,483,666.69$ & 2 & $44,741,833.34$ & & \\
\hline & Within groups & $177,789,569.70$ & 1033 & $172,109.94$ & 259.96 & $0.00^{* *}$ \\
\hline & Total & $267,273,236.40$ & 1035 & & & \\
\hline \multirow{3}{*}{ AGCS } & Between groups & $20,956,004.11$ & 2 & $10,478,002.05$ & & \\
\hline & Within groups & $41,771,163.30$ & 1033 & $40,436.75$ & 259.12 & $0.00^{* *}$ \\
\hline & Total & $62,727,167.41$ & 1035 & & & \\
\hline \multirow{3}{*}{ BGCS } & Between groups & $10,854,014.11$ & 2 & $5,427,007.05$ & & \\
\hline & Within groups & $31,761,162.30$ & 1033 & $30,746.52$ & 219.11 & $0.00^{* *}$ \\
\hline & Total & $42,615,176.41$ & 1035 & & & \\
\hline \multirow{3}{*}{ LFCS } & Between groups & $20,000,198.00$ & 2 & $10,990,000.00$ & & \\
\hline & Within groups & $8,101,614.98$ & 1033 & $93,122,011.00$ & 118.03 & $0.00^{* *}$ \\
\hline & Total & $300,000,008.00$ & 1035 & & & \\
\hline
\end{tabular}

Note: DBH, diameter at breast height; AGB, aboveground biomass; AGCS, aboveground carbon stock; BGCS, belowground carbon stock; LFCS, litterfall carbon stock. ${ }^{* *}$ indicates significant difference among the three types of oak at $P<0.01$ level.

Figure 3 shows the amount of carbon stocks in different carbon pools of the three types of oak. In this study, carbon stocks included aboveground and belowground tree components and litterfall, i.e., AGCS, BGCS and LFCS. The maximum value of carbon stocks was found in seed-originated oak and followed by coppice oak. The minimum value of carbon stocks was found in mixed oak. In addition, AGB accounted for the highest percentage of carbon stocks, ranged from $52.64 \%$ in 
mixed oak to $53.49 \%$ in seed-originated oak. AGCS in coppice oak accounted for $52.93 \%$ of the total carbon stocks. In the belowground component, the percentages were almost equal for all the three types of oak. LFCS accounted for $2.21 \%, 3.06 \%$ and $3.38 \%$ of the total carbon stocks for seed-originated, mixed and coppice oaks, respectively.
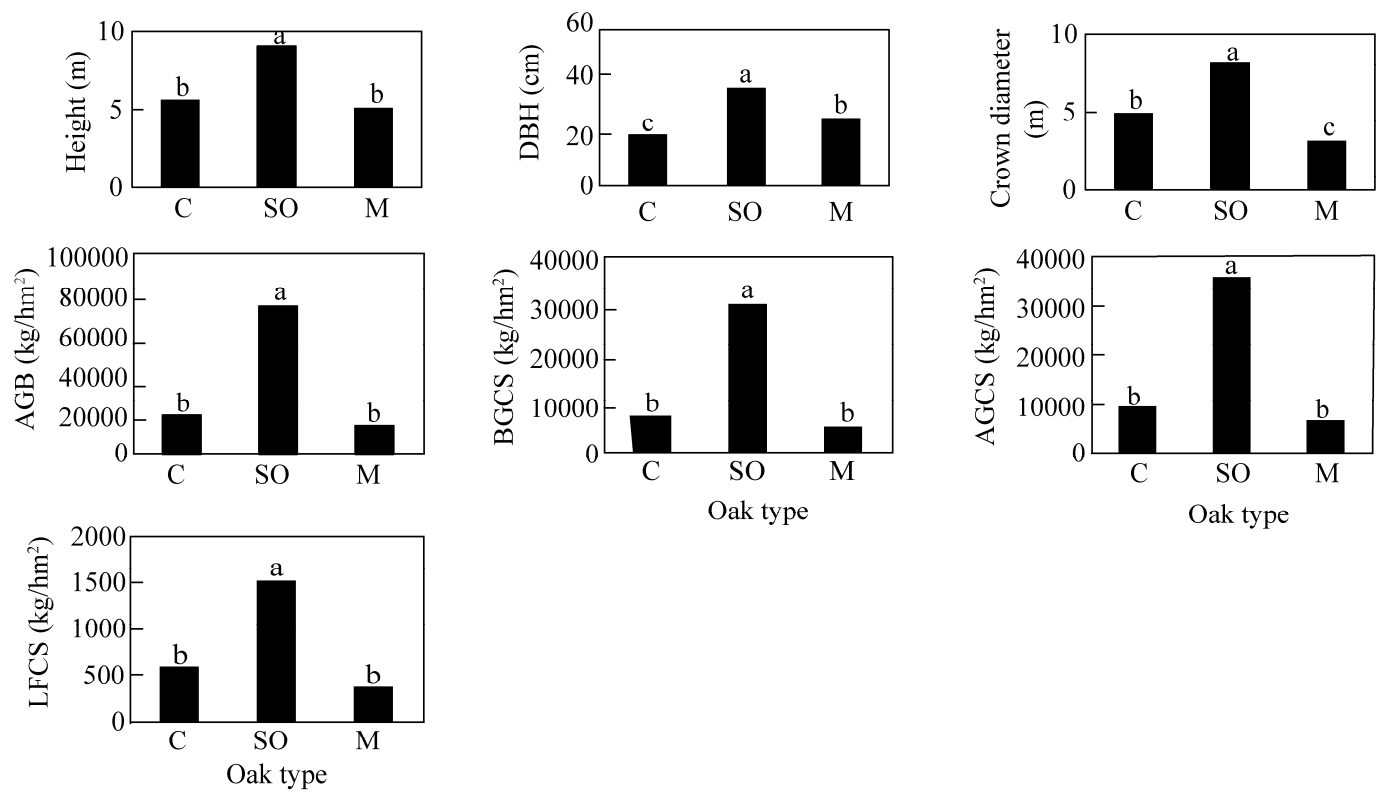

Fig. 2 Mean values of variables of the three types of oak. DBH, diameter at breast height; AGB, aboveground biomass; AGCS, aboveground carbon stock; BGCS, belowground carbon stock; LFCS, litterfall carbon stock; C, coppice oak; SO, seed-originated oak; MF, mixed oak. Different lowercase letters indicate significant difference among the three types of oak at $P<0.05$ level.

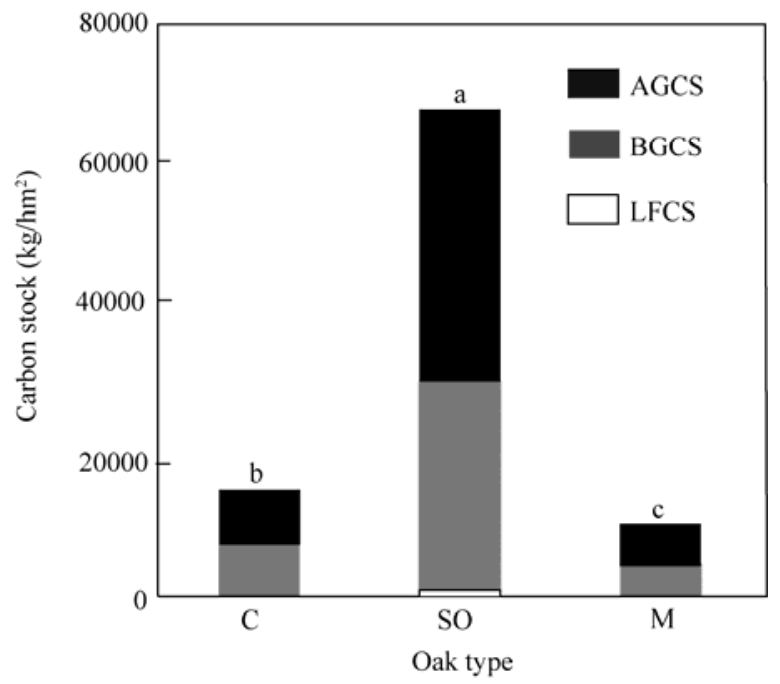

Fig. 3 Carbon stocks in different carbon pools of the three types of oak. AGCS, aboveground carbon stock; BGCS, belowground carbon stock; LFCS, litterfall carbon stock. C, coppice oak; SO, seed-originated oak; MF, mixed oak. Different lowercase letters indicate significant difference among the three types of forest at $P<0.05$ level.

\section{Discussion}

We observed three types (coppice, seed-originated and mixed oaks) of regeneration in Persian oak of Zagros forests in Dalab valley, Ilam Province, Iran. Therefore, knowledge of biomass and 
carbon stocks of this species, especially in coppice oak (the dominant forest type) may play an important role in valuing the ecosystem and management planning of Zagros forests (Zianis et al., 2005; Iranmanesh et al., 2014). Results indicate that biomass and carbon stocks were significant different among the three types of oak. In this study, the average biomass and carbon stocks of each tree or sprouts were 113.02 and $53.71 \mathrm{~kg} / \mathrm{hm}^{2}$ for mixed oak, 152.33 and $73.81 \mathrm{~kg} / \mathrm{hm}^{2}$ for coppice oak, and 786.65 and $380.05 \mathrm{~kg} / \mathrm{hm}^{2}$ for seed-originated oak, respectively, which had significant difference $(P<0.05)$ among the three types of oak (Table 3$)$. From the result, we can found that average biomass of trees in seed-originated oak was approximately five times higher than those of trees or sprouts in coppice and mixed oaks. Previous study found that AGB and AGCS were positively related to DBH, height and crown diameter of the tree (Ali et al., 2016). Therefore, this result is probably due to the presence of larger trees in seed-originated oak than sprouts in coppice oak (Table 1). The estimated average biomass and carbon stocks of spouts in coppice oak in this study were almost similar to the result of Iranmanesh et al. (2014) (146.3 and $70.7 \mathrm{~kg} / \mathrm{hm}^{2}$, respectively), but contrasted with the result of Alinejadi et al. (2016) (230.0 and $115.0 \mathrm{~kg} / \mathrm{hm}^{2}$, respectively). Moreover, the average biomass of single tree $\left(786.65 \mathrm{~kg} / \mathrm{hm}^{2}\right)$ in seed-originated oak was higher than the estimations of Iranmanesh et al. (2014) and Alinejadi et al. (2016) $\left(374.1 \mathrm{~kg} / \mathrm{hm}^{2}\right.$ and $252.0 \mathrm{~kg} / \mathrm{hm}^{2}$, respectively). The reason for this discrepancy in biomass of seed-originated oak may be due to the variations in characteristics, structure, stand density, proportion of large trees, productivity and history of forests in these regions (Tran et al., 2013; Mensah et al., 2016; Wang et al., 2016).

Seed-originated oak had the highest values of AGB $\left(76,043.25 \mathrm{~kg} / \mathrm{hm}^{2}\right)$ and AGCS $(36,737.79$ $\mathrm{kg} / \mathrm{hm}^{2}$ ), compared with other two stands (Fig. 3). Our findings are similar to the studies of Iranmanesh et al. (2014) and Alinejadi et al. (2016), who found that biomass and carbon stocks per hectare were higher in seed-originated oak than in coppice oak. Despite the similarity of results, the estimated biomass and carbon stocks of seed-originated oak in this study were approximately four times higher than those in Iranmanesh et al. (2014) and Alinejadi et al. (2016). The difference in AGB and AGCS among the three types of oak probably arise from forest structure, stand age and illegal wood cutting (Askari et al., 2017). Forest structure is original and identical in seed-originated stand in comparison with the other two types of oak. As shown in Table 1, the distribution of trees was almost uniform in the first two classes of DBH (i.e., $<30$ and $30-60 \mathrm{~cm}$ ) in seed-originated oak. Also crown diameter plays an important role in the total biomass of Persian oak trees and there are more trees with big crown diameter in seed-originated oak. However, the coppice shoots had different stems because of variations in their sprouting capacity. Crown diameter in the coppice shoots is smaller than that in seed-originated oak (Table 1; Iranmanesh et al., 2014). Another important factor for biomass partitioning within a tree species is tree age. With increasing age, the proportion of stem in the biomass becomes more important. Then proportion of canopy biomass increases with increasing tree size. Thus, forest intervention and transformation from original forest to destroyed forest are the main factors that cause changes in forest biomass (Peichl and Arain, 2007; Sanquetta et al., 2011).

The results of the study showed that litterfall contained carbon stocks of 379.91-1520.48 $\mathrm{kg} / \mathrm{hm}^{2}$ (Table 2; Fig. 3). Litter layer is a significant reservoir of carbon in forest ecosystems especially in soil organic carbon stock (Lorenz and Lal, 2010). Litter biomass and carbon stocks in seed-originated oak is significantly higher than other two types of oak because of the more number of trees per hectare and the wider crown of trees. Litter layer, which result from the annual amount of litterfall accumulation, plays an important role in forest carbon budgets (Lorenz and Lal, 2010). According to previous study, forest litter and soils store approximately 3-fold more carbon than living plants (Wang et al., 1999), and carbon pool of litter layer may store $5 \%-20 \%$ of the total stand carbon storage (Karjalainen, 1996).

Our findings showed that total carbon sequestration $\left(68,675.57 \mathrm{~kg} / \mathrm{hm}^{2}\right)$ in seed-originated oak was significantly higher than the other two types of oak. A similar trend to the reports of Iranmanesh et al. (2014) and Askari et al. (2017) was found in Zagros forests. The highly variable of the total biomass and carbon stocks in studied forests is supported by the strong role of structural variable of forests, which could also be used to management practices and conservation plans. 


\section{Conclusions}

In this study, we estimated the biomass and carbon stocks of aboveground and belowground tree components and litterfall among the three types of Persian oak. As expected, the origins of trees (seed or coppice) and forest structural variables including DBH, stand density and proportion of large trees in forests were found to explain a high variability of the estimated biomass and carbon stocks in studied forest types. The differences in biomass and carbon stocks in Zagros forests indicate the need for site-specific biomass and carbon stocks equations for the accurate assessment in these areas. Our result can help the managers and decision-makers to consider the role of Zagros forests in reducing atmospheric carbon dioxide and its carbon storage potential.

\section{Acknowledgements}

This research was funded by the Ilam University, Iran.

\section{References}

Ali A, Yan E R, Chen H Y H, et al. 2016. Stand structural diversity rather than species diversity enhances aboveground carbon storage in secondary subtropical forests in eastern China. Biogeosciences, 13: 4627-4635.

Alinejadi S, Basiri R, Tahmasebi K P, et al. 2016. Estimation of biomass and carbon sequestration in various forms of Quercus brantii Lindl. stands in Balout Boland, Dehdez. Iranian Journal of Forest, 8(2): 129-139. (in Persian)

Allen M R, Gillett N P, Kettleborough J A, et al. 2006. Quantifying anthropogenic influence on recent near-surface temperature change. Surveys in Geophysics, 27: 491-544.

Allen S E, Grimshaw H M, Rowland A P. 1986. Chemical analysis. In: Moore P D, Chapman S B. Methods in Plant Ecology London: Blackwell Scientific Publication, 285-344.

Askari Y, Soltani A, Akhavan R, et al. 2017. Assessment of root-shoot ratio biomass and carbon storage of Quercus brantii Lindl. in the central Zagros forests of Iran. Journal of Forest Science, 63(6): 282-289.

Becknell J M, Powers J S. 2014. Stand age and soils as drivers of plant functional traits and aboveground biomass in secondary tropical dry forest. Canadian Journal of Forest Research, 44(6): 604-613.

Brown S. 1996. Tropical forests and the global carbon cycle: estimating state and change in biomass density. In: Apps M J, Price D T. Forest Ecosystems, Forest Management and the Global Carbon Cycle. Heidelberg: Springer, 40.

Brown S. 2002. Measuring carbon in forests: Current status and future challenges. Environmental Pollution, 116(3): 363-372.

Chave J, Andalo C, Brown S, et al. 2005. Tree allometry and improved estimation of carbon stocks and balance in tropical forests. Oecologia, 145: 87-99.

Chen H Y H, Yong L. 2015. Net aboveground biomass declines of four major forest types with forest ageing and climate change in western Canada's boreal forests. Global Change Biology, 21: 3675-3684.

Hernandez R, Koohafkan P, Antoine J. 2004. Assessing Carbon Stocks and Modeling Win-win Scenarios of Carbon Sequestration through Land-use Changes. Rome: Food and Agriculture Organization of the United Nations (FAO), 18-24.

Iranmanesh Y. 2013. Assessment on biomass estimation methods and carbon sequestration of Quercus brantii Lindl. in Chaharmahal \& Bakhtiari forests. PhD Dissertation. Tehran: Tarbiat Modares University, 107. (in Persian)

Iranmanesh Y, Sagheb-Talebi K, Sohrabi H, et al. 2014. Biomass and carbon stocks of Brant's oak (Quercus brantii Lindl.) in two vegetation forms in Lordegan, Chaharmahal \& Bakhtiari forests. Iranian Journal of Forest and Poplar Research, 22(4): 749-762. (in Persian)

Jepsen M R. 2006. Above-ground carbon stocks in tropical fallows, Sarawak, Malaysia. Forest Ecology and Management, 225(1-3): 287-295.

Karjalainen T. 1996. Dynamics and potentials of carbon sequestration in managed stands and wood products in Finland under changing climatic conditions. Forest Ecology and Management, 80(1-3): 113-132.

Lexerød N L, Eid T. 2006. An evaluation of different diameter diversity indices based on criteria related to forest management planning. Forest Ecology and Management, 222(1-3): 17-28.

Lorenz K, Lal R. 2010. Carbon Sequestration in Forest Ecosystems. New York: Springer, 277.

MacDicken K G. 1997. A Guide to Monitoring Carbon Storage in Forestry and Agroforestry Projects. Arlington: Winrock International Institute for Agricultural Development, 84-87.

Mensah S, Veldtman R, Du T B, et al. 2016. Aboveground biomass and carbon in a South African Mistbelt forest and the relationships with tree species diversity and forest structures. Forests, 7(79): 1-17. 
Nunes L, Lopes D, Rego F C, et al. 2013. Aboveground biomass and net primary production of pine, oak and mixed pine-oak forests on the Vila Real District, Portugal. Forest Ecology and Management, 305: 38-47.

Pearson T R H, Brown S L, Birdsey R A. 2007. Measurement guidelines for the sequestration of forest carbon. In: General Technical Report NRS18. United States Department of Agriculture (USDA) Forest Service. Tennessee, USA.

Peichl M, Arain M A. 2007. Allometry and partitioning of above and belowground tree biomass in an age-sequence of white pine forests. Forest Ecology and Management, 253(1-3): 68-80.

SaghebTalebi K, Sajedi T, Pourhashemi M. 2014. Forest of Iran, a Treasure from the Past, a Hope for the Future. New York: Springer, 157.

Sanquetta A P, Silva F S. 2011-Biomass expansion factor and root-to-shoot ratio for Pinus in Brazil. Carbon Balance and Management, 6(6): 1-8.

Sohrabi H, Bakhtiarvand-Bakhtiari S, Ahmadi K. 2016. Above and belowground biomass and carbon stocks of different tree plantations in central Iran. Journal of Arid Land, 8(1): 138-145.

Soltani A, Angelsen A, Eid T. 2014. Poverty, forest dependence and forest degradation links: evidence from Zagros, Iran. Environment and Development Economics, 19(5): 607-630.

Tran D B, Dargusch P, Herbohn J, et al. 2013. Interventions to better manage the carbon stocks in Australian Melaleuca forests. Land Use Policy, 35: 417-420.

Wang K B, Deng L, Ren Z P, et al. 2016. Dynamics of ecosystem carbon stocks during vegetation restoration on the Loess Plateau of China. Journal of Arid Land, 8(2): 207-220.

Wang W, Lei X, Ma Z, et al. 2011. Positive relationship between aboveground carbon stocks and structural diversity in spruce dominated forest stands in New Brunswick, Canada. Forest Science, 57: 506-515.

Wang Y, Amundson R, Trumbore S. 1999. The impact of land use change on C turnover in soils. Global Biogeochemical Cycles, 13(1): 47-57.

Zhang Y, Chen H Y H. 2015. Individual size inequality links forest diversity and aboveground biomass. Journal of Ecology, 103: 1245-1252.

Zianis D, Muukkonen P, Mäkipää R, et al. 2005. Biomass and stem volume equations for tree species in Europe. Silva Fennica. Monographs 4: 63. 